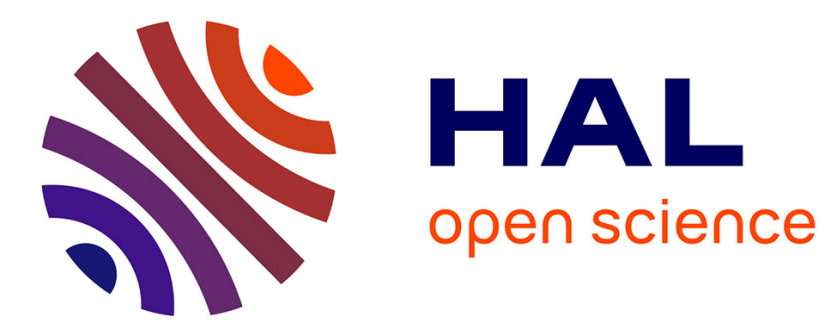

\title{
Clusters, Proximities and Networks
}

Christophe Carrincazeaux, Michel Grossetti, Damien Talbot

\section{To cite this version:}

Christophe Carrincazeaux, Michel Grossetti, Damien Talbot. Clusters, Proximities and Networks. European Planning Studies, 2008, 16 (5), pp.613-616. 10.1080/09654310802049091 . hal-03389778

\section{HAL Id: hal-03389778 https://hal.science/hal-03389778}

Submitted on 21 Oct 2021

HAL is a multi-disciplinary open access archive for the deposit and dissemination of scientific research documents, whether they are published or not. The documents may come from teaching and research institutions in France or abroad, or from public or private research centers.
L'archive ouverte pluridisciplinaire HAL, est destinée au dépôt et à la diffusion de documents scientifiques de niveau recherche, publiés ou non, émanant des établissements d'enseignement et de recherche français ou étrangers, des laboratoires publics ou privés. 


\title{
GUEST EDITORIAL
}

\section{Clusters, Proximities and Networks}

\author{
CHRISTOPHE CARRINCAZEAUX*, MICHEL GROSSETTI** \& \\ DAMIEN TALBOT* \\ *Université Montesquieu Bordeaux IV, Pessac, France, ${ }^{* *}$ Université de Toulouse, LISST, EHESS, Toulouse, \\ France
}

In the Marshallian tradition of industrial districts, alongside theories of regional systems (Cooke, 2001), national innovation systems (Lundvall, 1992), local productive systems (Courlet \& Soulage, 1994) or innovative environments (Camagni \& Maillat, 2006), the cluster concept is usually treated in its spatial dimension, considering quite correctly that geographic proximity between firms constitutes a real factor in the diffusion of information and knowledge (Porter, 1998). The current international fascination with the concept of clusters, both amongst politicians and economic researchers, is rooted in the hypothesis that proximity displays characteristics that are conducive to the preservation and even reinforcement of relationships, irrespective of the area of activity in question. Policies encouraging the polarization of innovation activities are based on the following reasoning (Torre, 2006): (1) for innovation to occur, knowledge must be produced or appropriated; (2) by its very nature, knowledge cannot be appropriated in its entirety, and this induces effects wherein the knowledge spills over to other companies; (3) inasmuch as distance constitutes an obstacle to the diffusion of tacit knowledge — which can only be transferred via imitation and practice-geographic proximity is conducive to diffusion.

A proximity-based approach offers a complementary analysis of the concept of clusters, transcending a geographic proximity approach per se and incorporating a broader notion of coordination. Since agents are present both "here and elsewhere" (Rallet, 1999)— here since they are located in a geographic space within which they entertain relationships with neighbours, elsewhere because actors clearly entertain remote relationships with other agents-a person can be "near" someone from whom s/he is geographically distant. The idea here is that alongside spatial proximity, there is also such a thing as a relational type of non-spatial proximity. Geographic proximity is a representation that individuals have of the distance that separates them in space from objects and/or other individuals (Torre \& Rallet, 2005). Since this assessment is made from a distance, it is relative in two different ways:

Correspondence Address: D. Talbot, Université Montesquieu Bordeaux IV, GREThA - UMR 5113, Avenue Léon Duguit, 33608 Pessac, France. Email: damien.talbot@u-bordeaux4.fr 
because the distance is weighted by transportation time and costs, as a result of the material structuring of space; and because the distance that separates individuals, organizations or cities is also a representation, a judgement that causes people to see themselves, in a binary fashion, as being situated "close" or "far away". This conception of geographic proximity is based on an enriched conception of space, apprehended as an active construction of relationships and not as a simple functional context. According to the authors, non-spatial proximity is related, albeit not exhaustively, to organized proximity (Torre \& Rallet, 2005), socio-economic proximity (Bouba-Olga \& Grossetti, 2008) and institutional and organizational proximities (Talbot \& Kirat, 2005; Talbot, 2008) (cf. Carrincazeaux et al., in this issue, on the scientific trajectory of the French Proximity School). Everyone agrees that proximity's relational aspect should be construed (much like geographic proximity) both as a potential that can facilitate coordination and also as a constraint (cultural limitations to cooperation, negative externalities, etc.) (Pecqueur \& Zimmermann, 2004). The idea here is that the conditions for coordination, apprehended as constructs, need to be updated. All in all, interlinking these two types of proximity provides an analytical vision of the way actors coordinate themselves in a geographic space. Here clusters are viewed as a paradigmatic example covering the fundamental categories of proximity.

This special issue ${ }^{1}$ adheres to the latter vision by offering a series of articles that study how a cluster's actors link proximity's spatial and non-spatial dimensions in their relationships with other agents. It is in this linkage between local and global connections, between the here and the elsewhere, and in the recombination of knowledge that this enables, that we will be able to see clusters as open systems more than as closed ones. Where innovation processes are involved, it is important to show that although diffusion within the knowledge cluster is crucial for innovation, it is also important to transfer knowledge about the environment towards the cluster. Here we will need a network concept alongside our proximity construct to emphasize the importance of the relational dimension of the innovation process, specifically because it enables a linkage of the local with the non-local.

We start with a contribution by C. Carrincazeaux, Y. Lung and J. Vicente, who offer a historical analysis of the scientific trajectory of a group of French researchers, called "Dynamics of Proximity". After revisiting the group's leading publications, the authors outline the main issues characterizing this school of thought, presented as research agenda items. Two main questions are how should proximity be measured and what role does proximity play between interactions and institutions. The former theme may not be explicitly discussed in this issue, but the latter does play a major role. In actual fact, this was the title of the Fifth Annual Proximity Conference held in June 2006 at Bordeaux, which gave birth to the articles featured here.

M. Grossetti's article belongs to this latter school of thought and focuses on different levels of action. He demonstrates the need to distinguish relationships between individuals and relationships between organizations (firms, research laboratories, public organizations for economic development). The effects of spatial proximity are easier to understand when we analyse the interactions between these levels of action. Relationships between individuals help to establish relationships between organizations, but once launched, these can become autonomous and pursue their own logic. The existence of a local inter-individual network encourages local exchanges between organizations, without turning them into prisoners of said networks. Above all, it highlights the importance of the "mediation resources" that help to liberate people from interpersonal 
networks. Here, the effects of proximity derive from the geography of networks and from mediation resources. They are not explained by the need to transfer tacit knowledge.

ITFs (International Trade Fairs) are one of the mediation resources that companies use to access non-local partners. M. Ramírez-Pasillas, in a study of the Lammhult cluster in Sweden, has analysed how firms mobilize spatial and relational proximities to accentuate the transfer of ITFs' knowledge towards clusters. The author shows that firms located in the cluster acquire knowledge due to their participation in these ITFs, knowledge that is then recombined and diffused within the cluster via local networks. The combination of networks and mediations (ITFs) produces a cluster that is localized yet also connected to international exchange flows.

Along these same lines, F. Belussi, A. Sammarra and S. R. Sedita detect, within a "life science cluster" located in Emilia-Romagnia (Italy) and comprised of firms and public research organizations, the presence of an "open innovation model". They note that, within a cluster, firms' innovation benefits as much from geographic proximity as from social embeddedness, interactions with local institutions, knowledge spillovers and globalization processes that multiply the sources of innovation, thanks for example to cooperation efforts with international actors. They also show that a positive relationship exists between “external R\&D networking, in-house R\&D investment, and innovative performance", for both firms and public research organizations. In short, this is a promising opening.

J. Wickham and A. Vecchi then underline the importance of global connections in creating local knowledge and sparking innovation. In a study of the "Irish Software industry in Dublin", they highlight links between business travel and cluster dynamics, studying the way in which global links are constructed and maintained by different "relational arrangements".

Lastly, J. M. Zuliani adheres to a vision of clusters construed as open systems in a study on the growing porosity of certain sectors of activity. He notes that product-based or branch of activity-based analysis is becoming less and less effective at characterizing industrial clusters' productive organization. One example is provided by embedded systems produced in Toulouse, which developed initially as per a sectorial logic before progressively shifting due to the convergence of competencies and knowledge held by the aeronautical, spatial and automobile electronic industries. What we have here are local prime contractors sharing subcontracted information technology (IT) services; examples of cooperation between industrialists and engineering academies; and staff movements within a local labour market. This has led to the emergence of a "local system of competencies", one whose specificities are situated upstream of the products that firms sell.

The convergence of the articles compiled here illustrates the fertility of approaches based on a detailed analysis of coordination and networks at different levels. These approaches show that the existence of local configurations like clusters is not contrary to the growth of non-local exchanges, since it results from a complex architecture of individual networks, inter-firm relationships and different mediation systems.

\section{Note}

1. The present issue is partially derived from communications made at the Fifth Annual Proximity Conference, entitled "Proximity, between interactions and institutions", held in Bordeaux in June 2006 and funded by the Aquitaine Regional Authority. Some of the texts presented here were translated as part of the "Trajectories of innovation" programme, also funded by the Aquitaine Region. 


\section{References}

Bouba-Olga, O. \& Grossetti, M. (2008) Socio-économie de proximité, in: O. Bouba-Olga, C. Carrincazeaux \& M. Coris (Eds), special issue of Revue d'Economie Régionale et Urbaine "La proximité, 15 ans déjà!", 3, forthcoming.

Camagni, R. \& Maillat, D. (Eds) (2006) Milieux Innovateurs. Théories et Politiques (Paris: Economica Anthropos).

Cooke, P. (2001) Regional innovation systems, clusters, and the knowledge economy, Industrial and Corporate Change, 10, pp. 945-974.

Courlet, C. \& Soulage, B. (1994) Industries, Territoires et Politiques Publiques (Paris: L'Harmattan).

Lundvall, B. A. (1992) National Systems of Innovation: Towards a Theory of Innovation and Interactive Learning (London: Pinter Publishers).

Pecqueur, B. \& Zimmermann, J. B. (Eds) (2004) Economie de Proximités (Paris: Hermès, Lavoisier).

Porter, M. (1998) Clusters and the new economics of competition, Harvard Business Review, 76(6), pp. 77-90.

Rallet, A. (1999) L'économie de proximités. Communication à l'école-chercheur INRA, Le Croisic, 8-10 December.

Talbot, D. (2008) Les institutions créatrices de proximités, in: O. Bouba-Olga, C. Carrinacazeaux \& M. Coris (Eds), special issue of Revue d'Economie Régionale et Urbaine "La proximité, 15 ans déjà!", 3, forthcoming.

Talbot, D. \& Kirat, T. (Eds) (2005) Proximités et institutions: nouveaux éclairages, Economie et Institutions, 6 \& 7.

Torre, A. (2006) Clusters et systèmes locaux d'innovation, Retour critique sur les hypothèses naturalistes de la transmission des connaissances à l'aide des catégories de l'economie de la proximité, Région et Développment, 24, pp. 15-44.

Torre, A. \& Rallet, A. (2005) Proximity and localization, Regional Studies, 39(1), pp. 47-60. 